\title{
Peer Attachment dan Student Engagement pada Siswa Pondok Pesantren
}

\author{
Mitha Rohmatul Jannah'1, Jainudin ${ }^{1}$ \\ 1Fakultas Psikologi dan Kesehatan UIN Sunan Ampel Surabaya
}

DOI: http://doi.org/10.29080/jpp.v\%vi\%i.239

\begin{abstract}
Student engagement is reflected from students' interest, attention, and their effort in process of learning. This research aims to study a correlation between peer attachment and student engagement. This quantitative research design involved 67 students whom are selected by probability sampling techniques. Data analysis used correlation product moment analysis. The results showed that there was a positive correlation between peer attachment and student engagement boarding school students. On the other words, when students have good peer attachment then they will have high student engagement.
\end{abstract}

Kata kunci : Peer attachment, Student engagement

\begin{abstract}
Abstrak : Student engagement terlihat dari wujud ketertarikan, perhatian, dan usaha siswa dalam proses pembelajaran. Penelitian ini bertujuan untuk melihat hubungan melihat hubungan peer attachment dengan student engagement. Rancangan kuantitatif ini melibatkan 67 siswa yang dipilih dengan teknik probability sampling. Analisis data yang digunakan adalah analisis product moment. Hasil penelitian menunjukkan adanya hubungan antara peer attachment dengan student engagement pada siswa MA pondok pesantren. Dengan kata lain semakin baik peer attachment yang dimiliki maka itu membuat student engagement siswa semakin kuat.
\end{abstract}

Kata kunci : Peer attachment, Student engagement

\section{Pendahuluan}

Keterlibatan siswa dengan sejumlah kegiatan di sekolah mempunyai dampak positif dan cenderung akan membuat prestasi mereka meningkat. Keterlibatan dalam kegiatan belajar adalah ketika siswa berperilaku secara intensif, memiliki kualitas emosi, dan siswa meluangkan waktu untuk dapat terlibat selama kegiatan belajar (Reeve \& Jang, 2006). Tanpa adanya student engagement yang baik, maka proses belajar yang baik pun sulit terlaksana. Student engagement dapat meningkatkan efikasi diri (Mustika \&

Corresponding Author: Mitha Rohmatul Jannah (e-mail: mitharj@gmail.com) Program Studi Psikologi Fakultas Psikologi dan Kesehatan UIN Sunan Ampel Surabaya, Jl. A. Yani 117 Surabaya Jawa Timur, Indonesia 60237 
Kusdiyati, 2015), nilai akademik yang lebih baik serta nilai ujian yang lebih tinggi (Lawson, 2011). Tingkat perhatian, emosi positif, usaha dan komitmen dari seorang siswa dalam proses belajarnya menjadi indikator penting dari student engagement (Handelsman, Briggs, Sullivan, \& Towler, 2005). (Reeve \& Jang, 2006) menjelaskan bahwa semakin tinggi tingkat engagement seorang siswa maka semakin baik pula proses belajarnya.

Student engagement dalam kegiatan akademik merupakan proses psikologis yang melibatkan ketertarikan, perhatian, investasi dan usaha siswa yang diwujudkan dalam proses pembelajaran (Marks, 2000). Fredricks, Blumenfeld, \& Paris (2004), menyatakan bahwa keterlibatan siswa merupakan hal yang menarik karena melibatkan banyak gagasan termasuk pengamatan behavioral engagement, emotional engagement dan cognitive engagement. Student engagement memiliki banyak dampak positif dalam proses pembelajaran baik bagi siswa, guru maupun sekolah. Pada umumnya, siswa yang memiliki student engagement memiliki emosi yang positif, penuh energi, antusias, totalitas dalam menjalankan tugas dan perannya sebagai siswa serta memiliki rasa yang tinggi untuk menjalankan peraturan yang ada di sekolah dan mempunyai sikap disiplin (Schaufeli, dkk., 2002).

Salah satu faktor yang mempengaruhi student engagement ialah hubungan teman sebaya (Fredricks et al., 2004). Adanya teman sebaya dapat membuat siswa merasa enjoy ketika melakukan berbagai aktivitas pembelajaran (Arifani, 2018). Sejalan dengan penelitian Wang \& Eccles (dalam Gunawan, Fransisca, Tiatri, \& Sri, 2017) yang mengatakan bahwa siswa akan lebih terlibat secara perilaku dan emosi di sekolah jika memiliki hubungan baik dengan teman sebaya. Hal ini sesuai dengan penelitian (Arifani, 2018), yang menemukan bahwa peer attachment memiliki pengaruh yang besar terhadap keterlibatan siswa dalam proses belajar mengajar di sekolah. Hubungan pertemanan yang baik dan lebih lekat akan membuat siswa lebih nyaman dalam kegiatan di sekolah dan terlibat aktif dalam proses belajar mengajar. Santrock dalam (Fiana, Daharnis, \& Ridha, 2013) juga menyatakan bahwa proses interaksi dengan teman sebaya dapat mempengaruhi, merubah, dan memperbaiki perilaku individu yang lain.

Menurut Armsden \& Greenberg (1989) peer attachment adalah persepsi individu tentang sejauh mana ia dan teman-teman sebayanya dapat saling memahami, menghargai, berkomunikasi dengan baik, dan mendapatkan rasa aman dan nyaman dari relasinya tersebut. Ketika remaja merasa membutuhkan teman sebayanya, ia akan cenderung mencari kenyamanan dan kedekatan baik dalam bentuk saran ataupun nasihat kepada teman sebayanya. Kedekatan dan kenyamanan tersebut merupakan salah satu hal penting yang dapat mewujudkan perilaku student engagement pada siswa.

Dari hasil wawancara dan observasi yang dilakukan pada santri pondok pesantren As Salafi Al Fithrah Surabaya, mereka dituntut untuk mampu melewati tuntutan akademik dan sejumlah kegiatan yang dilakukan baik di pondok maupun disekolah. Mereka harus berusaha giat menyelesaikan tugas dan hafalan, berkonsentrasi saat belajar, dan mematuhi aturan sekolah dan pondok. Pada umumnya santri melewatkan banyak waktu untuk menghafal di pondok sehingga sering berinteraksi dengan teman sesama penghafal al qur'an. Santri yang memiliki kelekatan pertemanan sesama penghafal al qur-an, akan lebih nyaman mengikuti kegiatan disekolah dan lebih giat dalam menghafal al qur'an karena memiliki tujuan yang kuat. Lingkungan pertemanan yang berjalan dengan baik dan menyenangkan menumbuhkan keterikatan antar siswa. Peneliti menduga bahwa peer attachment mempengaruhi munculnya student engagement sehingga penelitian ini bertujuan untuk mengetahui bagaimana hubungan peer attachment dan student engagement pada santri pondok Pesantren. 


\section{Metode Penelitian}

Penelitian ini menggunakan rancangan kuantitatif (korelasional) yang melihat hubungan peer attachment sebagai variabel bebas dengan student Engagement (keterlibatan siswa) sebagai variabel terikat. Populasi dalam penelitian ini adalah siswa MA Pondok Pesantren Al Fitrah Surabaya kelas XI SMA, baik laki-laki maupun perempuan berjumlah 205. Teknik pengambilan sampel yang digunakan adalah simple random sampling. Simple random sampling adalah teknik pengambilan sampel dari populasi yang dilakukan secara acak tanpa memperhatikan strata yang ada dalam populasi itu (Sugiyono, 2010). Jumlah sampel yang digunakan dalam penelitian ini sebanyak 67 siswa.

Alat ukur yang digunakan adalah skala peer attachment yang modifikasi dari penelitian yang dilakukan oleh Wardhini (2017). Alat ukur tersebut disusun untuk mengukur kelekatan siswa dengan teman sebaya yang rajin dan baik yang terdiri dari 21 aitem yang valid dengan koefisien reliabilitas $(\alpha)$ sebesar 0,822 . Adapun alat ukur student engagement menggunakan Inventory of Parent and Peer attachment (IPPA) yang dikembangkan oleh Armsdern dan Greenberg (2009) meliputi aspek-aspek trust, communication, dan alienation. Analisis data menggunakan uji korelasi Product Moment untuk mengetahui hubungan antar kedua variabel.

\section{Hasil Penelitian}

Berdasarkan analisis statistik inferensial yang dilakukan terhadap hasil penelitian, maka dapat dijelaskan hubungan variable peer attachment dengan student engagement melalui tabel berikut ini:

Tabel 1

Hasil Uji Korelasi Product Moment

\begin{tabular}{|c|c|c|c|}
\hline \multicolumn{4}{|c|}{ Correlations } \\
\hline & & Peer attachment & Student engagement \\
\hline \multirow[t]{3}{*}{ Peer attachment } & Korelasi Pearson & 1 & $.412^{* *}$ \\
\hline & Sig. (2-tailed) & & .001 \\
\hline & Jumlah Subjek & 67 & 67 \\
\hline \multirow[t]{3}{*}{ Student engagement } & Korelasi Pearson & $.412^{* *}$ & 1 \\
\hline & Sig. (2-tailed) & .001 & \\
\hline & Jumlah Subjek & 67 & 67 \\
\hline
\end{tabular}

Hasil koefisien korelasi diperoleh signifikansi sebesar $0.001(0.001<0.05)$ dan menunjukkan korelasi yang bersifat positif $(+)$ yang artinya adanya hubungan yang searah. Dengan kata lain semakin positif siswa mempersepsikan peer attachment maka semakin tinggi pula student engagement siswa. Selanjutnya hasil uji korelasi product moment menunjukkan koefisien korelasi sebesar 0,412 dengan taraf kepercayaan 0.05 $(5 \%)$.

Tabel 2

Koefisien Determinasi

\begin{tabular}{lrrrr}
\hline & $\mathrm{R}$ & R Squared & Eta & Eta Squared \\
\hline $\begin{array}{l}\text { StudentEngagement } \\
\text { PeerAttachment }\end{array}$ & .412 & .170 & .743 & .552 \\
& & & & \\
\hline
\end{tabular}


Adapun nilai koefisien korelasi $\mathrm{R}=0.412$ menunjukan adanya korelasi antara peer attachment dengan student engagement dengan nilai koefisien determinasi $\mathrm{R}$ Square = 0.170. Artinya peer attachment memiliki pengaruh sebesar $17 \%$ terhadap student engagement, selebihnya student engagement dapat dipengaruhi oleh faktor lain.

Selanjutnya ada sejumlah data deskriptif yang dapat ditampilkan dari penelitian ini yaitu jenis kelamin dan prestasi yang dihasilkan.

Tabel 3

Deskripsi Data Berdasarkan Jenis Kelamin

\begin{tabular}{cccc}
\hline & Jenis Kelamin & $\mathrm{N}$ & Mean \\
\hline \multirow{2}{*}{ Student engagement } & Laki-laki & 32 & 85,46 \\
\cline { 2 - 4 } & Perempuan & 35 & 86,59 \\
\hline \multirow{2}{*}{ Peer attachment } & Laki-laki & 32 & 98,62 \\
\cline { 2 - 4 } & Perempuan & 35 & 104,94 \\
\hline
\end{tabular}

Tabel 3 menunjukkan distribusi responden yang terdiri dari 32 responden lakilaki dan 35 perempuan. Nilai rata-rata tertinggi student engagement ada pada subjek perempuan yaitu sebesar 86,59 sedangkan untuk peer-attachment juga pada subjek perempuan sebesar 104,94.

Tabel 4

Deskripsi Data Berdasarkan Prestasi

\begin{tabular}{cccc}
\hline Jumlah Prestasi & $\mathbf{N}$ & Mean & Std. Deviasi \\
\hline Tidak pernah & 8 & 87,23 & 9,392 \\
$\underline{1 \text { kali }}$ & $\underline{19}$ & $\underline{83,79}$ & $\underline{7,598}$ \\
2 kali & 30 & 87,75 & 7,157 \\
\hline$>2$ kali & 10 & 85,10 & 5,343 \\
\hline Tidak pernah & 8 & 95,25 & 14,038 \\
$\underline{1 \text { kali }}$ & $\underline{19}$ & $\underline{97,05}$ & $\underline{9,902}$ \\
2 kali & 30 & 105,03 & 10,959 \\
\hline$>2$ kali & 10 & 107,20 & 13,950 \\
\hline
\end{tabular}

Tabel 4 menggambarkan distribusi responden dengan pebcapaian prestasi yang dimiliki. Delapan responden dalam penelitian in tidak pernah mendapatkan prestasi, 19 responden pernah 1 kali mendapatkan prestasi, 30 responden mendapatkan 2 kali prestasi dan 10 responden mendapatkan prestasi lebih dari 2 kali. Selanjutnya nilai ratarata tertinggi untuk variabel student engagement ada pada responden yang mendapatkan prestasi 2 kali dengan nilai mean sebesar 87,75. Sedangkan nilai rata-rata tertinggi pada variabel peer attachment terdapat pada responden yang mendapatkan prestasi lebih dari 2 kali dengan nilai mean sebesar 107,20. Dengan kata lain responden yang banyak prestasinya memiliki nilai student engagement dan peer attachment yang tinggi juga

\section{Pembahasan}

Dari hasil uji analisis korelasi, didapatkan nilai signifikansi sebesar 0,001 >0,05 yang berarti hipotesis nol (Ho) ditolak dan hipotesis alternatif (Ha) diterima. Dengan kata lain terdapat hubungan antara peer attachment dengan student engagement pada siswa. Selain itu, penelitian ini juga menunjukkan nilai koefisien korelasi yang positif yaitu 0,412 sehingga arah hubungannya adalah positif dimana semakin positif persepsi siswa tentang 
sebuah ikatan kelekatan dengan teman sebaya maka semakin baik pula keterikatan siswa di sekolah (student engagement). Hal ini sesuai dengan pernyataan (Fredricks et al., 2004) bahwa hubungan teman sebaya telah diketahui dapat mempengaruhi behavioral, cognitive dan emotional engagement, yang merupakan tiga aspek student engagement.

Hasil penelitian ini juga menunjukkan adanya kontribusi variabel peer attachment terhadap perilaku student engagement. Lingkungan pertemanan yang berjalan dengan baik dan menyenangkan, dapat menumbuhkan perilaku student engagement yang tinggi pada siswa. Hal itu juga diungkapkan oleh (Li, Doyle Lynch, Kalvin, Liu, \& Lerner, 2011) dimana siswa remaja yang memiliki hubungan dan komunikasi yang baik antar teman sebaya akan cenderung lebih aktif untuk terlibat (engage) secara emosi dan perilaku dalam berbagai kegiatan sekolah. Begitu pun dengan Bergin \& Bergin (2009) yang mengatakan bahwa adanya kelekatan yang aman, baik dengan orangtua, guru maupun teman sebaya akan memberikan pengaruh terhadap keberhasilan siswa di sekolah.

Adanya peer attachment membuat siswa merasa lebih nyaman untuk berinteraksi dengan teman-teman disekitarnya. Hal ini akan membuat siswa lebih bersemangat untuk menyelesaikan tugas-tugas dan tantangan dalam setiap proses pembelajaran disekolah (Marks, 2000). Shernoff dalam (Arifani, 2018) menyatakan bahwa hubungan teman sebaya merupakan sebuah dukungan dari teman sebaya yang diberikan kepada individu untuk mendukung kegiatan akademik di sekolah. Peer attachment diberikan dalam bentuk dukungan rasa percaya dan hubungan emosional. Hubungan dengan teman sebaya akan memberikan kekuatan yang potensial dalam membentuk sebuah perilaku siswa di sekolah (Arifani, 2018) (Wentzel K R, 2003).

Hasil penelitian ini memiliki kesamaan dengan penelitian-penelitian sebelumnya tentang hubungan peer attachment dengan student engagement. Penelitian sebelumnya yang dilakukan (Arifani, 2018) mengatakan bahwa peer attachment berhubungan dengan student engagement karena meningkatnya peer attachment akan meningkatkan kecenderungan terjadinya student engagement. Dengan peer attachment yang tinggi maka siswa mampu mengontrol perilaku untuk mempertahankan usaha dalam mengerjakan tugas, berpartisipasi secara aktif baik didalam kelas maupun diluar kelas sehingga mereka akan mudah mencapai kondisi student engagement. Begitupun Brown dalam (Kupersmidt, 2003) mendapatkan hasil dalam penelitiannya bahwa kelekatan teman sebaya adalah salah satu hal penting untuk meningkatkan keterlibatan siswa di sekolah. Sedangkan (Lynch, Lerner, \& Leventhal, 2013) juga menyatakan bahwa siswa akan menjadi lebih terlibat secara aktif dalam kegiatan akademik di sekolah jika adanya kualitas pertemanan yang baik.

Penelitian ini juga didukung oleh beberapa data demografi untuk menjabarkan lebih rinci keadaan subjek penelitian yang kaitannya dengan peer attachment dan student engagement. peneliti mencantumkan data demografi seperti jenis kelamin, nilai rata-rata, dan jumlah prestasi non akademik yang pernah diraih. Pada penelitian ini diketahui bahwa student engagement lebih tinggi pada siswa yang berjenis kelamin perempuan dibandingkan laki-laki. Hal ini sesuai dengan penelitian yang dilakukan oleh (Marks, 2000) yang menyebutkan bahwa siswa perempuan akan lebih terikat dibandingkan siswa lakilaki. Hal ini dapat terlihat ketika interaksi dikelas atau dalam proses belajar mengajar siswa perempuan lebih aktif seperti menjawab pertanyaan guru ataupun bertanya, dibandingkan siswa laki-laki lebih memilih diam ketika ditanya.

Ada perbedaan tingkat peer attachment siswa pada siswa laki-laki dengan perempuan. Diketahui bahwa siswa perempuan memiliki kelekatan yang tinggi dengan teman sebayanya dibandingan dengan laki-laki. Hal ini dikarenakan siswa perempuan ingin memiliki pola interaksi yang lebih eksklusif dengan teman-temannya, baik secara emosional maupun fisik (Marks, 2000) (Birch \& Ladd, 2003). Clark dan Ayers dalam (Kupersmidt, 2003) juga mengatakan bahwa sejalan dengan bertambahnya usia, perempuan ingin lebih mengembangkan pola kelekatan dan persahabatannya. Sedangkan 
pola pertemanan siswa laki-laki cenderung pada pola pertemanan kompetisi. Kualitas pertemanan pada siswa yang berjenis kelamin perempuan tersebut, lebih membuat siswa merasa nyaman untuk berinteraksi dengan teman-temannya. Hal ini juga dapat membuat tingkat student engagement pada siswa perempuan lebih tinggi dibanding siswa laki-laki.

Apabila ditinjau dari nilai rata-rata, siswa yang mendapatkan nilai 8 memiliki student engagement yang lebih tinggi dibandingkan yang mendapatkan nilai 7 . Selain itu prestasi yang pernah diraih sebanyak 2 kali memiliki student engagement yang tinggi dibandingkan dengan siswa yang hanya sekali bahkan tidak pernah mendapatkan prestasi. Hal ini membuktikan bahwa student engagement sangat berpengaruh terhadap kesuksesan akademik. Untuk memaksimalkan kegiatan akademik di sekolah, maka setiap siswa seharusnya memiliki student engagement dengan melibatkan aspek tingkah laku, aspek kognisi, serta aspek emosi dalam kegiatan proses belajar di sekolah. Memaksimalkan proses belajar di sekolah agar siswa lebih memahami materi pembelajaran di sekolah dengan baik dan mencapai prestasi yang baik pula.

Berdasarkan korelasi tersebut dapat disimpulkan bahwa persepsi atas ikatan kelekatan dengan teman sebaya yang dimiliki siswa akan meningkatkan student engagement pada siswa. Hal ini menunjukkan bahwa semakin positif persepsi siswa tentang sebuah ikatan kelekatan dengan teman sebaya, sejauh mana ia dapat saling memahami dan berkomunikasi dengan baik semakin baik pula keterikatan siswa di sekolah (student engagement). Dan sebaliknya semakin rendah persepsi siswa atas ikatan kelekatan dengan teman sebaya, maka semakin rendah pula student engagement pada siswa. Mencermati paparan tersebut, dapat disimpulkan bahwa peer attachment pada siswa MA pondok pesantren Al Fitrah kelas XII merupakan salah satu faktor yang berpengaruh bagi adanya student engagement pada siswa.

\section{Simpulan dan Saran}

Berdasarkan penelitian yang diperoleh, terbukti secara empiris bahwa kedua variabel penelitian memiliki hubungan yang bersifat positif. Hal tersebut mengindikasikan bahwa semakin tinggi peer attachment pada siswa, maka semakin tinggi pula perilaku student engagement. Begitu pula sebaliknya, semakin rendah peer attachment pada siswa, maka semakin rendah pula perilaku student engagement yang ditunjukkan. Peer attachment memiliki kontribusi yang kecil terhadap student engagement, sehingga masih terdapat sejumlah faktor lain yang dapat menjadi ide penelitian selanjutnya yang berkaitan dengan student engagement.

\section{Daftar Pustaka}

Arifani, A. D. (2018). Peer Attachment dan Student Engagement pada Siswa SMA.

Armsden, G. C., \& Greenberg, M. T. (1989). Inventory of parent and peer attachment (IPPA). University of Washington Seattle, WA.

Bergin, C., \& Bergin, D. (2009). Attachment in the classroom. Educational Psychology Review, 21(2), 141-170.

Fiana, F. J., Daharnis, D., \& Ridha, M. (2013). Disiplin siswa di sekolah dan implikasinya dalam pelayanan bimbingan dan konseling. Konselor, 2(3).

Fredricks, J. A., Blumenfeld, P. C., \& Paris, A. H. (2004). School engagement: Potential of the concept, state of the evidence. Review of Educational Research, 74(1), 59-109.

Gunawan, F. A., Fransisca, I., \& Tiatri, S. (2017). Hubungan Peer Support dengan School Engagement pada Siswa SD. Jurnal Muara Ilmu Sosial, Humaniora, Dan Seni, 1(2).

Handelsman, M. M., Briggs, W. L., Sullivan, N., \& Towler, A. (2005). A measure of college student course engagement. The Journal of Educational Research, 98(3), 184-192. 
Li, Y., Doyle Lynch, A., Kalvin, C., Liu, J., \& Lerner, R. M. (2011). Peer relationships as a context for the development of school engagement during early adolescence. International Journal of Behavioral Development, 35(4), 329-342.

Lynch, A. D., Lerner, R. M., \& Leventhal, T. (2013). Adolescent academic achievement and school engagement: An examination of the role of school-wide peer culture. Journal of Youth and Adolescence, 42(1), 6-19.

Marks, H. M. (2000). Student engagement in instructional activity: Patterns in the elementary, middle, and high school years. American Educational Research Journal, 37(1), 153-184.

Mustika, R. A., \& Kusdiyati, S. (2015). Studi Deskriptif Student Engagement pada Siswa Kelas XI IPS di SMA Pasundan 1 Bandung.

Reeve, J., \& Jang, H. (2006). What teachers say and do to support students' autonomy during a learning activity. Journal of Educational Psychology, 98(1), 209.

Sugiyono. (2010). Metode Penelitian Pendidikan (pendekatan Kuantitatif, Kualitatif, dan $R \& D)$. Bandung: Alfabeta.

Wardhini, E. P. (2017). Hubungan Antara Peer Attachment Dengan Penyesuaian Sosial Pada Remaja Putri di Sekolah Homogen dan Tinggal di Asrama (Skripsi). Universitas Sanata Dharma Yogyakarta, Yogyakarta.

Wentzel K R. (2003). Socials goals and sosials relationships as motivators of school adjustment. Book of social motivation understanding children's school adjusment. 